\begin{tabular}{|l|l|l||}
\hline \multicolumn{2}{|c|}{ PublisherInfo } \\
\hline \hline PublisherName & $:$ & BioMed Central \\
\hline \hline PublisherLocation & $:$ & London \\
\hline \hline PublisherImprintName & $:$ & BioMed Central \\
\hline \hline
\end{tabular}

\title{
An encyclopaedia of mouse genes
}

\begin{tabular}{|l|l|l||}
\hline \multicolumn{2}{|c|}{ ArticleInfo } \\
\hline \hline ArticleID & $:$ & 3975 \\
\hline \hline ArticleDOI & $:$ & $10.1186 /$ gb-spotlight-20010208-02 \\
\hline \hline ArticleCitationID & $:$ & spotlight-20010208-02 \\
\hline \hline ArticleSequenceNumber & $:$ & 46 \\
\hline \hline ArticleCategory & $:$ & Research news \\
\hline \hline ArticleFirstPage & $:$ & 1 \\
\hline \hline ArticleLastPage & $:$ & 2 \\
\hline \hline & & RegistrationDate : 2001-02-08 \\
ArticleHistory & $:$ & OnlineDate $\quad$ 2001-02-08 \\
\hline \hline ArticleCopyright & $:$ & BioMed Central Ltd2001 \\
\hline \hline ArticleGrants & $:$ & \\
\hline \hline ArticleContext & $:$ & 130592211 \\
\hline \hline
\end{tabular}




\section{Kenneth Lee}

Email: kenlee_fr@yahoo.fr

An international consortium of scientists aiming to sequence every transcript encoded by the mouse genome has analysed 21,076 so far.

Estimates of the number of genes in the mammalian genome range from 30,000 to 200,000 . The problem is one of identifying which of the sequences in the billions of base pairs that make up the genome actually code for protein.

Instead of sequencing all $109 \mathrm{bp}$ in the mouse genome, an international consortium of scientists has been sequencing a large bank of cDNAs prepared from various mouse tissues and developmental stages. The scientists, co-ordinated by Yoshihide Hayashizaki of the RIKEN Genomic Sciences Centre in Japan, report the characterization of the first 21,076 of these cDNA clones in the 8 February Nature (Nature 2001, 409:685-690).

The consortium found, for example, more than 100 new genes that represent metabolic enzymes. Ten novel orthologues of genes implicated in human disease were also identified. Many of the cDNAs represented members of large multigene families associated with cellular differentiation and signal transduction, but few immune-related transcripts were identified. To enrich for these transcripts, Hayashizaki and his colleagues plan to prepare libraries from stimulated immune cells. They hope eventually to identify and sequence every transcript encoded by the mouse genome.

\section{References}

1. RIKEN Genomic Sciences Centre, [http://hgp.gsc.riken.go.jp/]

2. The RIKEN Genome Exploration Research Group Phase II Team and the FANTOM Consortium: Functional analysis of a full-length mouse cDNA collection. Nature 2001, 409:685-690., [http://www.nature.com/nature/]

This PDF file was created after publication. 